\title{
Histalog (Ametazole Hydrochloride) as a Substitute for Histamine in Determination of Maximal Acid Output
}

\author{
BRIAN A. SCOBIE,* M.B., CH.B., M.R.C.P., M.R.A.C.P.
}

Brit. med. F., 1965, 1, 1287-1288

In evaluating gastric secretory function by the augmented histamine test, headache and excessive drowsiness are often encountered. Less commonly, nausea, faintness, and hypotension may follow injection of the antihistamine or histamine. Thus a method which provides comparable secretory data with improved tolerance by the patient would be advantageous. Histalog (3-beta-aminoethyl pyrazole; ametazole hydrochloride ; betazole), a histamine analogue, may be preferable to histamine acid phosphate because of fewer side-effects (Kirsner and Ford, 1955). Even large doses, administered without an antihistamine drug, apparently are better tolerated than a " maximum" dose of histamine (Ward et al., 1963 ; Zaterka and Neves, 1964).

The present investigation sought to determine whether a standard dose of Histalog would yield one-hour acid outputs comparable with those after maximum histamine stimulation. The dose of $100 \mathrm{mg}$. of Histalog was selected because it was inferred from earlier work that it might be equivalent to a "maximum" dose of histamine (Ward et al., 1963). In addition, a detailed study was made of the incidence and severity of side-effects during the two types of test in order to determine whether the use of $100 \mathrm{mg}$. of Histalog might be preferable in clinical practice.

\section{Material and Methods}

Seventeen men and three women were studied, their ages ranging from 21 to 67 years (mean 47). Fifteen had duodenal ulcers, three had gastric ulcers, and two had no demonstrable lesion. Duplicate tests were performed on each patient-the augmented histamine test first and then, usually within one week, the Histalog test.

Basal and augmented histamine gastric analyses were performed by a modification of the Kay test (Card and Marks, 1960). After an overnight fast a rubber Levin tube (gauge $16 \mathrm{Fr}$.) was passed and the tip positioned in the antrum under fluoroscopic control. After aspiration of the resting-juice, basal secretion was collected for one hour by continuous machine suction at a pressure of $50 \mathrm{~cm}$. of water. The test was under constant supervision, and tube patency was checked frequently by syringe. Anthisan (mepyramine maleate) $50 \mathrm{mg}$. or $100 \mathrm{mg}$. if the patient weighed over $70 \mathrm{~kg}$.) was injected intramuscularly 20 minutes before the end of the basal hour period. Then histamine acid phosphate, $0.04 \mathrm{mg}$. $/ \mathrm{kg}$. of body weight, was injected subcutaneously and the gastric juice collected for one hour in four 15-minute aliquots. For the Histalog test the same procedure was used except that no antihistamine was given, and the gastric secretion was collected continuously for an additional hour after the 100-mg. intramuscular dose of Histalog to enable determination of peak acid output (Baron, 1962). The volume, $p \mathrm{H}$, and acid concentration were measured, using $0.1 \mathrm{~N} \mathrm{NaOH}$ and the indicator phenolphthalein. Volume was multiplied by acid concentration to derive the one-hour post-histamine and post-Histalog acid outputs respectively. Peak_30-minute acid outputs were calculated from the sum of the two consecutive 15-minute aliquots of maximum acid content.

*Visiting Physician, Hutt Hospital, Wellington, New Zealand.
During each test side-effects were recorded, particularly flush (graded 1 to 4 ), headache, nausea, faintness, and excessive drowsiness.

\section{Results}

In the 20 subjects the one-hour acid output after Histalog and after histamine correlated well (see Table). Although the mean one-hour acid output following Histalog was slightly lower than after histamine, the mean difference between the duplicate studies, $1.9 \mathrm{mEq} /$ hour, was not a significant one $(P=0.2)$.

\begin{tabular}{|c|c|c|c|c|c|}
\hline \multirow{2}{*}{$\begin{array}{l}\text { Subject } \\
\text { No. }\end{array}$} & \multicolumn{2}{|c|}{ One-hour $\underset{(\mathrm{mEq})}{\text { Acid Outputs }}$} & \multirow{2}{*}{$\begin{array}{l}\text { Subject } \\
\text { No. }\end{array}$} & \multicolumn{2}{|c|}{ One-hour Acid Outputs } \\
\hline & $\begin{array}{l}\text { After } \\
\text { Histamine }\end{array}$ & $\begin{array}{l}\text { After } \\
\text { Histalog }\end{array}$ & & $\begin{array}{l}\text { After } \\
\text { Histamine }\end{array}$ & $\begin{array}{l}\text { After } \\
\text { Histalog }\end{array}$ \\
\hline \multirow[t]{2}{*}{$\begin{array}{r}1 \\
2 \\
3 \\
4 \\
5 \\
6 \\
7 \\
8 \\
9 \\
10 \\
11\end{array}$} & \multirow[t]{2}{*}{$\begin{array}{l}33 \cdot 1 \\
23.4 \\
44 \cdot 6 \\
21 \cdot 0 \\
62.7 \\
27 \cdot 8 \\
16 \cdot 4 \\
14 \cdot 4 \\
24 \cdot 7 \\
30 \cdot 5 \\
28 \cdot 0\end{array}$} & \multirow[t]{2}{*}{$\begin{array}{l}27 \cdot 6 \\
23.2 \\
40 \cdot 3 \\
19 \cdot 1 \\
39 \cdot 3 \\
36 \cdot 1 \\
14.8 \\
17.5 \\
16 \cdot 1 \\
33.8 \\
20.6\end{array}$} & $\begin{array}{l}12 \\
13 \\
14 \\
15 \\
16 \\
17 \\
18 \\
19 \\
20\end{array}$ & $\begin{array}{r}28 \cdot 1 \\
21 \cdot 6 \\
28 \cdot 3 \\
32 \cdot 8 \\
51 \cdot 0 \\
9 \cdot 9 \\
6 \cdot 1 \\
34 \cdot 0 \\
39 \cdot 1\end{array}$ & $\begin{array}{r}29.8 \\
33.0 \\
22.1 \\
26.1 \\
55.9 \\
11.8 \\
6.4 \\
31.8 \\
31.8\end{array}$ \\
\hline & & & Means & $28 \cdot 8$ & 26.9 \\
\hline
\end{tabular}

Peak outputs after Histalog occurred during the second and third 15-minute periods in 2 patients, third and fourth in 7, fourth and fifth in 6, fifth and sixth in 2, and sixth and seventh in 3. After histamine, peak outputs were in the second and third 15-minute periods in 9 and in the third and fourth in 11 patients. Although the peak rate of secretion after Histalog occurred later than with histamine, this virtually reached a plateau by the third 15-minute period in all subjects. Thirtyminute peak acid outputs following Histalog and histamine correlated closely, the mean difference being only $0.4 \mathrm{mEq}$ $(\dot{\mathrm{P}}>0.25)$.

No disabling side-effects occurred. Mild to moderate drowsiness, encountered in most instances after histamine and Anthisan, was insignificant after Histalog. The mean grade of facial flush was 2.7 with histamine compared with 2.2 after Histalog. Headache was significant in four patients after histamine and in one after Histalog. Nausea was encountered in one patient after histamine and in another after Histalog. One patient subject to asthma was undisturbed by either test. None in this group developed pallor or hypotensive reactions.

\section{Discussion}

In the 20 patients the mean acid outputs in the hour following Histalog $100 \mathrm{mg}$. and histamine acid phospate $0.04 \mathrm{mg} . / \mathrm{kg}$. correlated closely. Ward et al. (1963) showed that, for the hour immediately following the secretagogue, mean acid outputs with $50 \mathrm{mg}$. of Histalog were not as high as those with a "maximum" dose of histamine, but the differences were just short of statistical significance. It could be inferred from other data of these workers that $100 \mathrm{mg}$. of Histalog produce one-hour outputs more closely in agreement with those after maximal histamine stimulation, and this was confirmed in the present study. 
It has been proposed that a more accurate index of maximum gastric secretory function is the "peak acid output," derived from the maximum post-histamine 30-minute output (Baron, 1962). Nevertheless it has been shown that the one-hour posthistamine acid output (Card and Marks, 1960) has a discriminatory value equal to that of the "peak acid output," and is thus the more practical and preferable index of secretion (de Moura and Correia, 1964). In the present study the peak acid outputs after $100 \mathrm{mg}$. of Histalog correlated very closely with those after histamine acid phosphate $0.04 \mathrm{mg} . / \mathrm{kg}$. However, peak rates of secretion were often delayed until the second hour after the Histalog, which necessitates prolongation of the test compared with the one-hour collection period of the augmented histamine test if this parameter is used.

The practical implication of the present study is that $100 \mathrm{rng}$. of Histalog may usefully replace histamine acid phosphate $0.04 \mathrm{mg} . / \mathrm{kg}$. in the determination of one-hour "maximum" acid outputs. In interpretation it will be possible to use secretory standards previously established for the augmented histamine test (Marks, 1961). Advantages of the use of this standard dose of Histalog are the fewer side-effects, the reduced likelihood of errors in dosage, and the lack of necessity for an antihistamine drug, which itself may produce untoward effects occasionally. In the elderly subject, especially where confirmation of achlorhydria is sought, a one-hour collection after $50 \mathrm{mg}$. of Histalog may be adequate (Ward et al., 1963).

\section{Summary}

In duplicate gastric analyses on 20 patients the mean onehour acid outputs following $100 \mathrm{mg}$. of Histalog (betazole hydrochloride) intramuscularly were comparable to those following a "maximum" dose of histamine. Flushing, headache, and drowsiness were less prominent with Histalog than after maximal histamine stimulation. It is concluded that Histalog $100 \mathrm{mg}$. may usefully substitute histamine acid phosphate $0.04 \mathrm{mg} . / \mathrm{kg}$. in the determination of one-hour maximum acid outputs, and that the results can be interpreted in the light of previously established standards for histamine.

- I am grateful to Dr. Bernard Lake, of Eli Lilly Ltd., Sydney, for generous supplies of Histalog, and to Mrs. C. Wesselingh, S.R.N., for conducting the tests.

\section{REFERENCES}

Baron, J. H. (1962). Proc. roy. Soc. Med., 55, 74

Card, W. I., and Marks, I. N. (1960). Clin. Sci., 19, 147. de Moura, M. C., and Correia, J. P. (1964). Amer. F. dig. Dis., 9, 669. Kirsner, J. B., and Ford, H. (1955). 3. lab. Clin. Med., 46, 307. Marks, I. N. (1961). Gastroenterology, 41, 599.

Ward, S., Gillespie, I. E., Passaro, E. P., and Grossman, M. I. (1963). Ibid., 44, 620 .

Zaterka, S., and Neves, D. P. (1964). Ibid., 47, 251.

\title{
Antibiotics in Recurrent Cholangitis
}

\author{
P. C. REYNELL,* D.M., F.R.C.P.
}

Brit. med. F., 1965, 1, 1288-1289

Repeated rigors, often associated with jaundice and vomiting, in a patient with presumptive biliary disease usually indicate cholangitis due to incomplete obstruction of the common hepatic or common bile-duct. The conventional treatment is surgical. This is right and proper, but occasionally the patient may refuse operation or the surgeon may be unwilling to operate owing to age, infirmity, or technical difficulties. The patient may then be given a short course of chemotherapy, and when the symptoms inevitably recur an attitude of hopelessness is apt to descend on patient and physician alike. This is a report of three such cases apparently cured by a prolonged course of antibiotics.

\section{Case Reports}

Case 1.-A 70-year-old man had cholecystectomy for gall-stones in 1955. Three years later he started to get recurrent attacks of jaundice. These were subsequently associated with rigors, confusion, and incontinence, and jaundice became persistent. When seen at home in 1960 he was weak and wasted, and was given a four-weeks course of tetracycline. A month after treatment he had had no further rigors but was still jaundiced, and liver-function tests showed: serum bilirubin $7.3 \mathrm{mg} . / 100 \mathrm{ml}$., serum alkaline phosphatase 45 K.A. units, plasma proteins normal, S.G.O.T. 180 units. Jaundice progressively faded and an intravenous cholangiogram showed poor visualization of the ducts. When last seen seven months after treatment he appeared to be quite well, with serum bilirubin $0.8 \mathrm{mg} . / 100 \mathrm{ml}$. and serum alkaline phosphatase 14 K.A. units. Four years after treatment he was known to be

* Consultant Physician, Bradford A Group Hospitals. alive and well and had had no further reason to consult his practitioner.

Case 2.-A 74-year-old woman was seen in July 1960 with a history of recurrent abdominal pains for seven years. Latterly these had been associated with irregular rigors, vomiting, and confusion. Short courses of penicillin and chloramphenicol had been ineffective. Liver-function tests were normal except for a serum alkaline phosphatase of 39 K.A. units. She had two further rigors after admission to hospital. There was no filling of the gall-bladder after an oral cholecystogram, but an intravenous cholangiogram showed dilated common and cystic ducts, with a faintly opacified gall-bladder which appeared to contain non-opaque stones. The patient refused operation and was discharged after a 10-day course of sulphamethoxypyridazine. Rigors continued with intermittent jaundice and loss of weight, and she was readmitted in March 1961. A further rigor occurred after admission, when serum bilirubin rose to $3.7 \mathrm{mg} . / 100 \mathrm{ml}$., serum alkaline phosphatase to $87 \mathrm{~K}$.A. units, and thymol turbidity was 7 units. She was regarded as unfit for surgery and discharged. Two months later she was seen at home, having rigors every week. She was disillusioned and depressed, and refused readmission to hospital. Dimethylchlortetracycline $150 \mathrm{mg}$. q.d.s. was given for four weeks, and has been continued thereafter in a dose of $150 \mathrm{mg}$. daily. She has had no further symptoms and was quite well 42 months later.

Case 3.-A 60-year-old man started to complain of recurrent abdominal pain in 1953. Four years later a barium-meal examination showed a small hiatal hernia and distortion of the duodenal cap. In 1959 the hiatal hernia was repaired and a partial gastrectomy was performed. He continued to complain of pain, and a year later developed rigors and vomiting. A cholecystogram showed no filling of the gall-bladder. At operation the bile-ducts were grossly distended and packed with " biliary mud." The gallbladder was removed, a large friable stone was extracted from the 